\title{
成人口蓋裂の言語訓練成績
}

\author{
川野 通夫*・一色 信彦**・萩尾 藤江*
}

\section{Results of Speech Therapy in 23 Adult Patients with Gleft Palate}

\author{
Michio Kawano, Nobuhiko Isshiki, Fujie Hagio \\ (Kyoto University)
}

The effect of speech therapy in adult patients with cleft palate had been assessed rather pessimistically. But recent advances in speech therapy have gradually changed this view of the prognosis.

This report deals with the results of speech therapy on 23 patients with cleft palate, as evaluated in terms of both articulatory disorders and hypernasality. Basically, our speech therapy consisted of 1 . control of air flow in the oral cavity, 2. auditory training, and 3. articulatory practice. For the enhancement of the velopharyngeal function, the "puff up one's cheek" procedure proved more effective than the customary blowing exercise. It should also be emphasized that the candidates for speech therapy be selected strictly on the basis of the findings of the aerodynamic inspection, auditory and radiographic examination of velopharyngeal function. The speech therapy at our clinic is mainly directed toward the correction of articulation disorders and slight velopharyngeal incompetence.

Various methods have been utilized to accelerate carrying-over the speech sounds which were corrected at the level of word into the level of passage or conversation. They are repetition of monosyllables, singing songs, practice in drama, and frequent use of the corrected sounds in daily conversation.

Another important aspect of speech therapy is associated with psychological problems of the patients with cleft palate speech. The solution of the problem, which will promote their social activity, can be achieved by active counselling of the patients or by application of the operant conditioning method.

\section{はじめに}

成人口蓋裂言語の治療は困難とされているが，我々は言語訓練の方法によっては著明な効果を上 げ得る事を発表してきた ${ }^{11}$.

その後屯「言語訓練は年齢的にみて無理」とか「治りにくい」とかいわれて訓練を断わられた り, 自分であきらめていたという成人口蓋裂患者の受診は引き続き増加している. 今回は前回発表 した10症例にさらに13症例を加え，口蓋裂言語訓練の要点とその結果について報告する. 


\section{I. 初診時所見}

1. 症例

炤和51年 6 月より昭和 54 年 8 月までに当科言 話外来を受診した成人几蓋裂患者 23 症例は表 1 の通りである。

初診時年㱓は19歳から50歳，男 7 例，女16例 で，初回口蓋形成年龄は生後数力月から27歳で ある。

なお，これら23症例の扂住地は近畿一円に 及び，通院所要時間は30分から 3 時間であっ た。また聴覚以外の他の障害を合併するのは， Klippel-Feil 症候群一例（4)）のみであった。

\section{2. 受診の動機}

受診の動機はもちろん「正常なととばを話し たい」ということであるが, 条人の年㱓, 社会 的地位などにより，動機の種類や強さにかなり の养がある。また，これらは閏診のとり才j, と
る人によっても当然変わるであろう.

以下例記すると大別して，(1)「職場であっと わかりやすく話し，管理職としての役割を果た すようになりたい」4例（(2)(6)(8)(19)， (2)「こ とばをなおして職場での適応をよくしたい」7 例((7)(9)(12)(15)(23)，(3)「将来の就職にそなえ たい」3 例（5)(1320)， (4)「今は家に閉じこも っているが，乙とばをよくして就職や結婚をし たい」6例（(1)(3)(411(14)(22)，(5)「子ぞものた めに正しい発音を身につけたい」3 例(16)1178) に分かれるが，いずれも生活の上で改めててと ばを意識するようになって発音を治したいと来 院したものである。

3. 鼻咽腔閉鎖機能

鼻咽腔閉鎖機能は音声の聴覚的判定と視診お よび pneumotachograph による空気力学的検

表 | 23

\begin{tabular}{|c|c|c|c|c|}
\hline 症 例 & 性 別 & 初唁年齢 & 職業 & 裂の種類 \\
\hline 1 & 女 & 21 & 家事手伝 & 口蓋裂 \\
\hline 2 & 男 & 30 & 公務員 & 唇裂・蓋裂 \\
\hline 3 & 女 & 23 & 家事手伝 & "1 \\
\hline 4 & 女 & 20 & " & 口蓋裂 \\
\hline 5 & 女 & 20 & 学 生 & 唇裂・口蓋裂 \\
\hline 6 & 女 & 50 & 病院薬剤士 & "I \\
\hline 7 & 女 & 25 & 縫製工 & "I \\
\hline 8 & 男 & 29 & 工 員 & "I \\
\hline 9 & 女 & 25 & タイピスト & 口蓋裂 \\
\hline 10 & 男 & 23 & 会社員 & 唇裂・口蓋裂 \\
\hline 11 & 女 & 21 & 家事手伝 & " \\
\hline 12 & 男 & 23 & 会社員 & " \\
\hline 13 & 男 & 20 & 学 生 & " \\
\hline 14 & 女 & 27 & 家事手伝 & 先天性鼻咽腔閉鎖機能不全 \\
\hline 15 & 女 & 24 & 会社員 & 口蓋裂 \\
\hline 16 & 女 & 34 & 主婦 & 先天性鼻咽腔閉鎖機能不全 \\
\hline 17 & 女 & 36 & 会社員 & $\prime \prime$ \\
\hline 18 & 女 & 36 & 主 婦 & "I \\
\hline 19 & 男 & 27 & 会社員 & 粘膜下口蓋裂 \\
\hline 20 & 男 & 23 & 学生 & 唇裂・日蓋裂 \\
\hline 21 & 女 & 19 & 会社員 & 口蓋裂 \\
\hline 22 & 女 & 27 & 家事手伝 & " \\
\hline 23 & 女 & 19 & 看護婦 & " \\
\hline
\end{tabular}


表 2 初診時の異常構音

\begin{tabular}{|c|c|c|c|c|c|c|}
\hline 症 例 & 声門破裂音 & 咽頭摩擦音 & 歪み音 & 省 略 & 鼻音 化 & 鼻腔構音 \\
\hline 1 & p.t.k.kj.ts. S.s. & & & & & \\
\hline 2 & p.t.k.kj.ts.tf. & & b.g.s. S. & & & \\
\hline 3 & p.t.ts. k. kj. & & s. $\int$. & & & \\
\hline 4 & t.ts.k.kj.s. & $\int$. & p. dz. & & dz. b. & \\
\hline 5 & & & ts. & p.t. k. kj. & & \\
\hline 6 & p.t. & & $\mathrm{n}$. & k. kj. & b. & \\
\hline 7 & p.t.k.kj. & & & & s. $\int$. & \\
\hline 8 & p.t.ts. k. kj & & d3. n. & & b. g. & \\
\hline 9 & t.ts. & s. $\int$. & s. $\int$. & $\mathrm{k}$. & p. & \\
\hline 10 & & & t. $\mathrm{k}$. & p. & & \\
\hline 11 & p.t.k.tf.d. & & & & & \\
\hline 12 & p.t.k.kj.ts.ts.d3. & & & & s. S. g. & \\
\hline 13 & t.ts.k.kj.s. J. & & & & & \\
\hline 14 & p.ts. kj. & & t. k. t $\int$. & & & \\
\hline 15 & & & ts. s. $\int$. & & & \\
\hline 16 & p.t.ts. k.t $\int . d z$. & & & & s. $\int$. & $\mathrm{i}$ \\
\hline 17 & & & & & p.t.s. $\int . d z$. & $\mathrm{i}$ \\
\hline 18 & p.t.ts. k. kj.t $\int$. & & dz. s. $\int$. & & & \\
\hline 19 & k. kj. & & t. ts. & & & \\
\hline 20 & p. t. k. & & & & & \\
\hline 21 & t. $\mathrm{k}$. & & & & & \\
\hline 22 & p.t. k. t $\int$. & & & & & \\
\hline 23 & p.t. k. & & & & & \\
\hline
\end{tabular}

査によって評価した。

その結果, 23 症例中17例は鼻咽腔閉鎖機能不 全あり， 3 例は鼻咽腔閉鎖機能限界值（criti$\left(\mathrm{cal}^{2)}\right)$ ，また 3 例は鼻呐腔閉鎖機能不全なしと 判定した.

これら全例とも当院で初回口蓋形成術を受け たことはない，鼻咽腔閉鎖機能不全17例にはま ず咽頭弁形成術を施し, 限界值 3 例之閉鎖機能 不全なし 3 例には初めから言語訓練を行った。

\section{4. 異常構音}

単語による構音検査の結果は表 2 の通りであ る.

全例に 2 個以上の声門破裂音や咽頭摩擦音, 歪み音などの異常構音がみられる。乙れら23症 例でみる限りでは, 他の子音への置換, 口蓋裂 傾向および側音化構音はみられなかったが, 〔 i 列音の鼻腔構音 2 例 (先天性鼻咽腔閉鎖
機能不全）があった。 そして, 最も多い異常構 音は〔p〕〔t〕〔k〕音などのいわゆる声門破 裂声による置換であった。

5 . 恥力損失

平均聴力損失が $20 \mathrm{~dB}$ 以上であった症例は表 3 の通りである.

このうち症例(2)は純音聴力検査では $800 \mathrm{~Hz}$ で左 $80 \mathrm{~dB}$, 右 $60 \mathrm{~dB}$ 亿達する高音域漸傾型混 合難聴であった。

これら聴力損失が言語訓練に及ぼす影響は軽 視できないが，乙の問題については別稿にゆず る.

6. 行動および性格

言語活動について問診内容をまとめると下記 の如くである.

(1)ほかの人がいるところで電話のベルが鳴っ 時た, 受話器をとらない, 全例。 
(2)電話にでた時, 話すのが苦痛でない， 1 例 (10), 苦痛である，22例（症例(10を除く全例） などあり，ての他に異性に対して電話をかりら れない，7例（(2)(4)(10(12)(20(23) があった.

(3)病院の外来で時々聞きとれない程声が小さ い, 9 例 (1)(2)(4)(5)(9(11)(22(23). このうち症 例(4)は言語訓練担当者以外の者が名前を呼んで あ返事ができなかった。

(4)学業終了後のようすでは, 就職したいけれ どことばを意識して家に閉じこすっている， 6 例（11(3)(411)(14)）があった。

\section{II. 言 語 訓 練}

\section{1. 術前訓練}

鼻咽腔閉鎖機能不全あり之判定された症例に ついては, 咽頭弁形成術までの期間, 患者の言 語改善への意欲を高め, 手術後の訓練期間を少 しでも短縮するために，術前に鼻孔を指で押さ えた状態で構音操作を教え,できれば文章朗読 レベルまでの改善をはかった。期間は手術まで の 6 力月以内, 指導回数は $2 \sim 22$ 回（1回約 40 分）であった。

\section{2. 呼気の口腔内操作}

言語訓練の中心となるのは, あくまで構音操 作の指導である。

構音訓練に先立ってしばしば行われる吹く訓 練, 特に強く吹く訓練 (hard blowing exercise）は当科では全く行わない。しかし, 咽頭 弁形成術後 1 力月経ってな招開鼻声の残るもの には, 次のような呼気の口腔内操作の指導を行 った，我々はこの中に軽く吹く訓練を含めてい る.

(1)呼気を鼻と口から交互に出す.

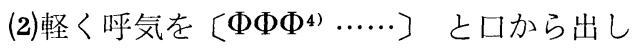
て，眼前の風車や紙片を動かす。

(3)煩をふくらませて, 口腔内に呼気を溜め,

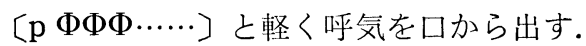

(4)鏡の前であくびの動作をして軟口蓋の挙上 を実際に見せたり，また口笛を吹く。そし てその時の筋感覚を説明する.
表 3 症例別聴力損失

\begin{tabular}{c|c|c}
\hline \multirow{2}{*}{ 症 例 } & \multicolumn{2}{|c}{ 平均聴力損失 $(\mathrm{dB})$} \\
\cline { 2 - 3 } & 左 & 右 \\
\hline 2 & 28 & 26 \\
4 & 57 & 32.5 \\
9 & 21 & 45 \\
10 & 25 & 30
\end{tabular}

\footnotetext{
韸）平均聴力損失 $=\frac{\mathrm{a}+2 \mathrm{~b}+\mathrm{c}}{4}$

( a : $500 \mathrm{~Hz}$, b : $1,000 \mathrm{~Hz}, \quad$ c $: 2,000 \mathrm{~Hz}$ )
}

\section{3.耳の訓練（ear training）}

正しい音と誤り音の弁別訓練や，いろいろな 音の中から訓練する音を聞き出す，いわゆる耳 の訓練をそれのみ単独で行うことはめったにな い. 構音操作の指導過程で, 患者の䛊った音を 録音で聞かせたり，訓練担当者が正しい音と患 者の䛊って出している音を模做して聞き分けさ せることで十分である，ただし，声門破裂音や 咽頭摩擦音, 鼻腔構音などはその音を聞かせて, 音の性質や構音点についてかなり詳しく説明す るようにしている.

\section{4. 構音訓練}

構音訓練の方法は, 前回音声言語医学 20 巻 3 号に発表したもの之同じである.内容が重複す るが，今回はもう少し詳しく記述する.

(1)〔p〕音の指導

前述した呼気の口腔内操作の指導に続き, 口 唇をはじくことから〔 $\mathrm{p}$ 音の指導を行う。こ のとき, 呼気が口から前に出るようにすること が大切である．そのために我々は，チリ紙（巾 $5 \mathrm{~cm}$ ，長さ $20 \mathrm{~cm}$ くらい）を患者の顔の前にたら し軽く息を出させたり，小さいローソクの灯を 吹き消させたりする方法を用いている.

患者が $[\Phi \Phi \Phi … .$.$] 之構音している時, 人$ さし指を口唇の下にそれと平行に置き, 指で下 口唇を下から上にはじくと, 瞬間的に唇が閉じ,

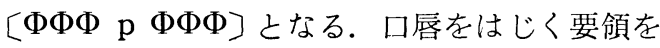


つかんだら，チリ紙を使わず「ФФФ…… と息 をロから前に出し，指を使わず軽く口唇をはじ

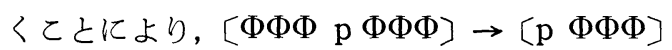
を出す.

また，煩をふくらませて，両煩を指で瞬間的 に強く押すととにより口唇をはじいて呼気を口

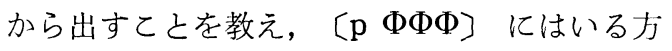
法も用いている.

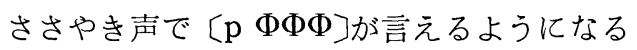

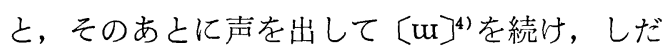

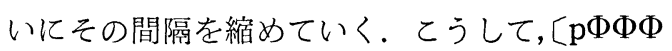
$+\mathrm{w}] \rightarrow[p \Phi \mathrm{w}] \rightarrow[p \mathrm{w}]$ へすすす

〔p u〕が単音筋で構音できるようになる

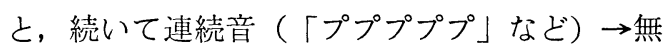
意味音節（意味のない音の組み合わせ「アプア

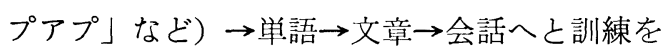
すすめる. 以下, $[\mathrm{k}]$ 音, $[\mathrm{t}]^{4)}$ 音, $\left[\int\right]^{4)}$ 音, $[\mathrm{s}]$ 音についても，ての訓練順序は同じである.

(2)〔k〕音の指導

〔k〕音の指導のポイントは奥舌の挙上であ る. 原則的に〔ka〕は〔ga〕から誘導する.

〔ga〕が出ない時は, まずうがいの練習から 始める.

(1)少量の水を口に含んで上を向く.

(2)上を向いたまま口を開け，しばらくそのま までいる。

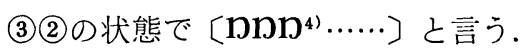

(4)うがいの要領で「ガラガラ」と音をたてる.

うがいができるようになると，今度は水を含 まないで [nnD…]と言い，そのあとに〔na 〕4) をつけて〔n-na $\rightarrow$ [ga $〕$ を導く．（音をたて てうがいができなくても(3)の状態から〔 へ導くこともできる)

単語で〔ga〕が正しく出るころになると, 〔ga〕から〔ka〕へ誘導する. これは〔ga〕の ささやき声のあとに〔ha〕をつけて, 〔k ha $]^{4)}$ $\rightarrow[\mathrm{kha}] \rightarrow[\mathrm{ka}]$ へ之訓練する.

(3)〔t〕音の指導

〔t〕音は上歯の裏あたりを舌尖ではじくこ とにより構音できる. 舌尖の動きが悪く、はじ
く力が弱い場合，次のような舌運動を促進する ための練習を平行して行う.

(1)うどんをすする.

(2)「ナンナンナン」または「ンーダンーダ」 を練習する.

(3)ズムとメロディをつけて「ランランラ ン」とか「リリロリロリロリ」などと歌う.

こうしながら，〔t〕音の指導は舌を口唇では さみ, ささやき声で〔pa〕と言うつもりで舌を 急に引っ込め, ささやき声〔ta〕を出す方法を 用いる.

あるいは, [na-1)〕と言って歯茎部の裏に舌 尖を挙上させ，勢いよくはじき落とすことから

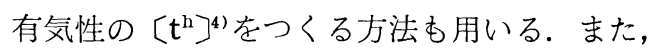
いきなりささやき声の〔ta〕を模做させるとと あある.（症例(10はてれを用いた）

〔t〕a〕が正しく構音できている場合, 舌尖 の動きに注意を向けさせ，ささやき声の〔 $\left.\mathrm{t} \int \mathrm{a}^{4}\right)$

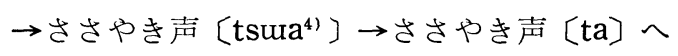
之漸次接近させていく方法もある.

ささやき声で〔ta〕が構音できるようになる と, 声を出して〔ta〕と言う.

(4) 〔 $\int^{3)}$ 音の指導

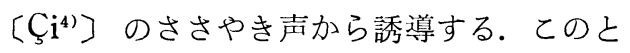
き, 呼気が上下の歯間から摩擦性の音として出

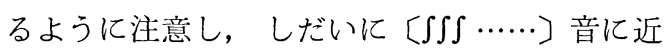
づける。

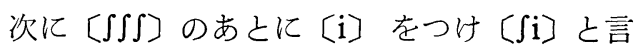
えるようにする。

(5)〔s〕音の指導

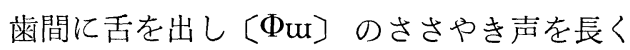

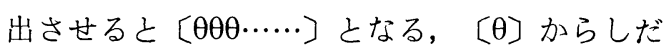
いに舌を引っ込め〔sss ……〕誘導する.

[sss〕が言えるようになったら，てれに母 音〔u〕をつけ〔su註4) と言えるようにす る.

成人口蓋裂患者は構音の悪習慣が身について いて, 単語を正しく構音するととまでは比較的 簡単にできるが, 会話では依然として過去の誤 った構音習慣にとらわれやすい. 正しい構音操 
表 4 言語訓練回数

\begin{tabular}{|c|c|c|c|c|c|c|c|c|c|c|c|c|c|}
\hline \multirow[b]{2}{*}{ 症例 } & \multicolumn{4}{|c|}{ 術前訓練 } & \multirow[b]{2}{*}{ 小計 } & \multicolumn{4}{|c|}{ 術後訓練 } & \multirow[b]{2}{*}{ 小計 } & \multirow{2}{*}{$\begin{array}{l}\text { 訓 練 } \\
\text { 総回数 }\end{array}$} & \multirow{2}{*}{$\begin{array}{l}\text { 合宿 } \\
\text { 回数 }\end{array}$} & \multirow{2}{*}{ 訓 練 } \\
\hline & 音節 & 単語 & 文章 & 会話 & & 音節 & 単語 & 文章 & 会話 & & & & \\
\hline 1 & 6 & 3 & 2 & & 10 & 4 & 3 & 21 & 13 & 34 & 44 & 3 & 20 力月 \\
\hline 2 & 2 & 1 & & & 2 & 1 & 2 & 2 & & 4 & 6 & 4 & 7 力月 \\
\hline 3 & 6 & 4 & 13 & & 18 & 3 & 2 & 7 & 1 & 10 & 28 & & 16 力月 \\
\hline 4 & 3 & 2 & 5 & & 10 & & & 13 & 20 & 28 & 38 & 2 & (26力月) \\
\hline 5 & 3 & 1 & 10 & 4 & 18 & & & & & & 18 & & 10 力月 \\
\hline 6 & 1 & 3 & 1 & & 4 & 3 & 1 & 4 & 1 & 9 & 13 & 2 & (27カ月) \\
\hline 7 & 7 & 1 & & & 7 & & 4 & 4 & 1 & 9 & 16 & 1 & 9 カ月 \\
\hline 8 & 4 & & & & 3 & 2 & 4 & 13 & 2 & 18 & 21 & 1 & (23力月) \\
\hline 9 & 1 & 4 & 4 & & 4 & 1 & 2 & 2 & 13 & 20 & 24 & & 12 力月 \\
\hline 10 & 3 & & 1 & & 4 & & & 5 & & 5 & 9 & 2 & 9 力月 \\
\hline 11 & & & & & & 2 & 4 & 6 & 2 & 12 & 12 & & (17カ月) \\
\hline 12 & 5 & 2 & 8 & 13 & 22 & & & & & & 22 & 1 & (18力月半) \\
\hline 13 & 10 & 7 & 8 & 1 & 16 & & & & & & 16 & 2 & ( 6 力月) \\
\hline 14 & 8 & 4 & 4 & 1 & 12 & & & & & & 12 & & 4 力月 \\
\hline 15 & 1 & 1 & & & 2 & 6 & & & & 4 & 6 & & 11 力月 \\
\hline 16 & & & & & & 9 & 3 & 6 & 3 & 8 & 8 & 2 & ( 6 力月) \\
\hline 17 & 10 & 8 & 5 & & 19 & 6 & 4 & 3 & & 10 & 29 & 1 & (11力月半) \\
\hline 18 & & & & & & 19 & 7 & & & 18 & 18 & & (15力月半) \\
\hline 19 & & & & & & 2 & & 2 & & 3 & 3 & & 3 力月 \\
\hline 20 & 7 & 5 & 6 & 5 & 15 & & & & & & 15 & 2 & (15力月) \\
\hline 21 & 3 & 1 & 3 & 8 & 12 & & & & & & 10 & & ( 5 力月半) \\
\hline 22 & & & & & & 6 & & 3 & 10 & 15 & 15 & & (12 力月半) \\
\hline 23 & & & & & & 3 & 2 & 1 & & 1 & 1 & 3 & ( 3 力月) \\
\hline
\end{tabular}

註）音節，単語など個々の訓練は 2 つ上平行に行うことがあるため, 加算しても小計, 訓練総合回数 とは合わない。訓練総期間の（）内は継続中のものを示す。

作を会話まで持ち込むためには，無意味音節で の訓練が重要である．特に，患者の訓練してい る音を他の言いにくい音と組み合わせた連続構 音の訓練（たとえば「カ」について「タカタカ 」「ナカカラ」など）を繰り返して行う。

このような無意味音節での訓練から単語, 文 章での訓練にすすみ，会話訓練として，歌，落 誠, 日常生活用語, 演劇, テーブル・スピーチ ，グループ・ディスカッションなどの指導をす る.

\section{5. 指導期間之回数}

術前, 術後訓練の期間之回数は表 4 の通りで ある。

合宿は患者数名と言語訓練担当者, ボランテ
ィアが院外で 1 ～泊するもので， 1 日 $6 \sim 7$ 時間におよぶ集中的な構音訓練と個人および集 団のカウンセリングなどを行っている.

\section{6. 心理的な指導}

心理的な指導としては大別して，カウンセリ ングと行動療法を用いている.

(1)カウンセリング

構音指導の後約 30 分, 患者の感情をありのま まに受容する非指示的なカウンセリングを実施 する. 最初 $2 \sim 3$ 回は全例に行い, あとは必要 に応じて行う.

また, 合宿の集団カウンセリングあ有効で, 患者同志，悩みを語り合う中で共感が生まれ， 自己受容と共に問題解決にふみ出そうとする構 
えができてくる，訓練者としても，院内ではみ られない患者の心理的, 社会的問題や性格など を知ることができ，その後の指導計画立案にも 役立つ。

(2)行動療法

(1)電話を苦手とするものがほとんどなので, 聴能訓練用電話器を用いて室内で訓練するてと から, 院内の外来加ら研究室への連絡, 院外か ら訓練者への連絡へとすすみ，順次電話をかけ る相手む広げ，回数も多くするよう指導する.

(2)口蓋裂児の山登りや合宿に，患者をボラン ティアとして参加させ，後で口蓋裂児の両親を 含めた懇談会を持つ。ここでは，患者は子どあ

\section{III. 結}

\section{1. 訓練終了時の基準}

訓練終了時の我々の基準は，(1)構音が「正常 」または「ほぼ正常」，(2)患者の話しことばに 対する自己評価，(3)行動上の変化の 3 つをむと にしている.

構音の「ほぼ正常」とは「会話時に時たま子 音が歪む程度に30分くらい話せる者, リラック スして早ロにしゃべる時は誤り音があってあよ いとしている.

行動上の変化とは「電話がかけられるように なった」「声が大きくなった」などから「自分 の希望する仕事についた」など患者の自己決定 能力の向上屯目安においている，構音改善の最 終判定は，なるべく会話時の観察を長時間，自 然に行える合宿でするようにしている.

\section{2 . 構音}

指導の結果, 構音の改善度は表 5 の通りであ る。「ほぼ正常」以上として構音訓練を終了し たもの；13例．広い意味で訓練中のもの；10例 である。このうち 4 例（4)(8)(12)(22）は文章訓練 を終了し，合宿による会話訓練を行っていて， 近日中に終了の見込みである.

症例包も会話訓練に入ったが，上顎急速拡大 術を受けたため訓練を中断している.

症例6は会話時に「時々わからないことばが
の持つ発達上の問題や，母親の子ぞもへの態度 （過保護，過干涉，安定した関係なご）を実際 にみることにより，自己の心理的問題を洞察す る機会を持つことになる.

また，症例(1)は大学の言語障害担当教員養成 課程特別専攻科へ研究生として入り，上り広く 言語障害について研修し，次は料理旅館で働き インターホンで 100 ～200名分の料理名を次々と 調理場に連絡するうち，会話時の構音と電話や 人との会話を避けようとする態度に大きな改善 をみた。

てのように進学や就職, 職場での適応にも行 動療法を取り入れて指導している.

\section{果}

表 5 構音訓練結果

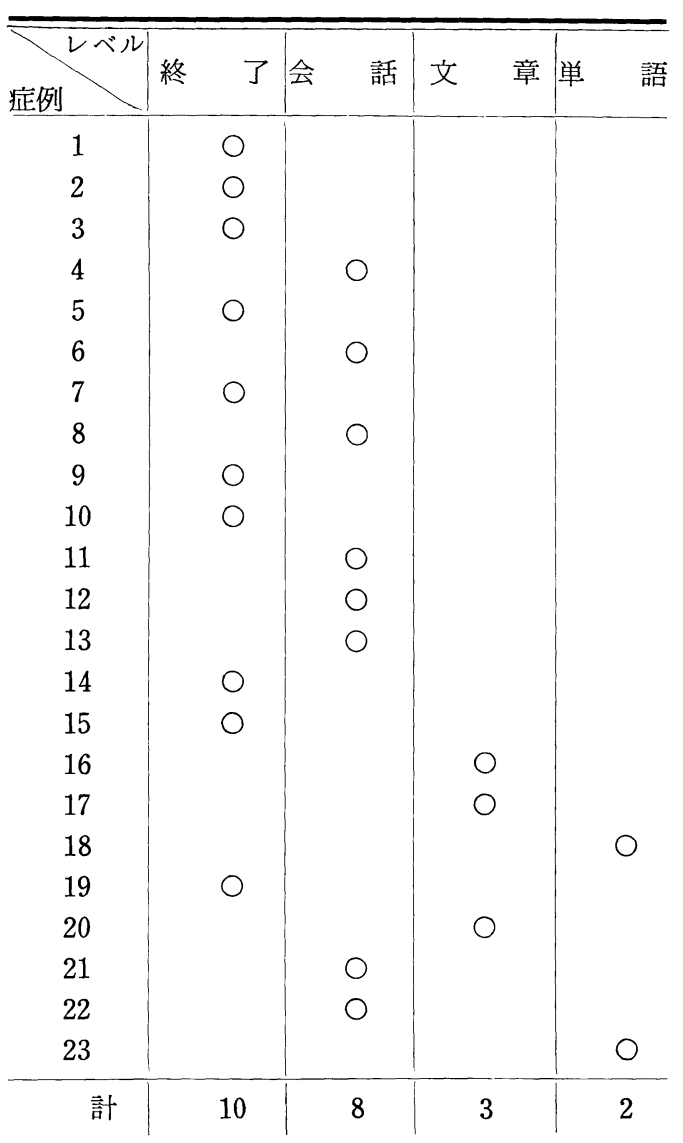


ある」が，管理職採用試験に合格し，時間的に 余裕がなくなったため，合宿に時々参加する程 度になっている。

残り 4 例（16)17 1823) は, 本人の構音しにく い無意味音節の訓練と文章朗読訓練を行ってい る.

前回報告した 3 例（(1)(2)(4)）に加えて，さら に4例（101213(14)）に軽い吃症状がみられた。 いずれも訓練 2 力月から 6 力月頃まででその後 自然に消失した。

3. 意識や行動の変化

\section{IV. 考}

最近では口蓋裂手術の成績向上とともに口蓋 裂言語をもつ患者はしだいに少なくなり，単に 口蓋裂患者の言語障害の予防, 訓練という観点 からだけでなく，言語指導は次のような内容を 持つようになってきた。

1 つは乳幼児期からの発達（運動, 探索・操 作，社会性，食事・排泄，衣服の着脱，言語な ぞ）やその基盤となる母一子関係の問題点を的 確に把握し，予後の見通しをたて必要な助言， 指導をするとと，もう1つは，年長患者の口蓋 裂言語（構音障害と開鼻声）と心理的な問題の 改善をはかることである，本論文では後者の問 題に焦点をあててみた。

これだけの症例ではまだ断定的なととは言え ないが，成人口蓋裂患者の構音改善は可能であ り，現在までの 23 例でみる限りでは構音改善ば かりでなく患者の意識・行動の変化でもかなり 満足すべき成績を得たと考えられる.

以下において，乙の成績をあげ得た要因と考 えられることと, 今後の問題点を考察する.

1. 鼻咽腔閉鎖機能の的確な評価

構音訓練を行う前に鼻咽腔閉鎖機能を的確に 評価する必要があるのは言を待たない, 鼻咽腔 閉鎖機能不全に気づかず構音訓練をいたずらに 長く続けたり，構音改善不可能とあきらめるの は全く意味がない。

成人口蓋裂患者の構音改善が長期訓練によっ
構音改善に伴う患者の話しうや自己意識, 行 動の変化にもめざましいものがある.

話すとき声が大きくなった；11例（1(1)(6)(7) (9)(10)(12)(13)(14)(22)，電話に気軽に出られるよう うになった；3 例（10)13199)，あまり抵抗感を 持たずに出られるようになった；14例（1)(2)(3) (4)(5)(6)(7)(8)(14)15(16.21(22).

これまで家に閉じこもっていたが衝くように なった；4 例 (1)(3)(4)(22). 自分の希望する職 場に転職したり，より上級のポストについた； 5 例（2(6)(7)(10) などである.

\section{察}

ても困難な場合，主に十分な鼻咽腔閉鎖機能が 得られなかったととによると考えられる，鼻咽 腔閉鎖機能不全を認めれば，程度により咽頭弁 形成術か言語訓練かを選ぶようにする。

23例中17例が鼻咽腔閉鎖機能不全で，乙のう ち16例はこれまでの手術で十分な閉鎖機能が得 られなかったあのであり，1例（22）は初診時 (27歳)まで未手術（軟口蓋裂）であった。

軽度鼻咽腔閉鎖機能不全（鼻咽腔抵抗值45～ 100 dyne. sec/ $\mathrm{cm}^{5}$ ) の 3 例（(5)(12)(14)）は全例, 言語訓練のみで，会話まで構音改善を得たか子 しくはその見通しをつけることができた。軽度 鼻咽腔閉鎖機能不全は言語訓練のみで構音改善 が可能な場合が多いと考えられる.

先天性鼻咽腔閉鎖機能不全の 4 例中, 年長者 の3 例（16)17 18）は幅広い咽頭弁を移植したに 屯かかわらず，術後 5 力月〜 1 年 1 力月の現在 依然として経鼻気流々出之開鼻声が残ってい

る.これら 3 例は, 咽頭側壁や軟口蓋および舌 の運動機能が悪く，2例（1618）には軽度精神 発達遅滞ああるので, 今後会話レベルまでの構 音改善は困難だと思われる。しばらく言語訓練 を続けた後, 再手術の適応について考慮するつ ありでいる.

Klippel-Feil 症候群の症例(8) は, 咽頭弁形 成術後も経鼻気流々出と開鼻声が残り, 言語訓 練を約 1 年間続けた後, 咽頭弁の右側に追加手. 
術をしたととろ，開鼻声がなくなり，間むなく 訓練を終了できるまでになった。

2．強く吹く訓練をしなかったてと

（煩をふくらませて呼気を出す訓練の意義） 従来，吹く訓練 (blowing exercise) につい ては賛否両論いまだ結論が出ていないようであ る. 我々はいわゆる強く吹く訓練は行わず，原 則として口唇音 (〔P〕音) の指導の中で, 患 者にでく軽く呼気をロから出すように求めるだ けである.

強く吹く訓練により軟口蓋の挙上や咽頭側壁 の動きが改善されるととああり得るが，それは あのをロにくわえて吹く時の動作であり, 構音 操作時の鼻咽腔閉鎖機能の改善には直接つなが らないと考えられる。

吹く訓練より，煩をふくらませて呼気を吹き 出す訓練の方が，(1)口唇を閉じる（弾力性をあ たせるようにはじくこともできる)，(2)軟口蓋 を挙上させ鼻咽腔閉鎖機能訓練となる，(3)口腔 内压上昇感覚をもつ，の 3 者を同時に習得でき るのでより望ましいと言える.

長期間吹く訓練をした患者の中には，軟口蓋 末端と咽頭後壁間の距離が大きいが，軟口蓋の 挙上や咽頭側壁の動きが驚くほどよく，単語ま では正確に構音できる者もいる.しかし, その大 部分は会話時には鼻咽腔閉鎖機能が不十分で, 構音がくずれ開鼻声を示す。呼気の口腔内操作 を教えることから始めて構音操作の訓練に入 り，6力月経過して屯鼻咽腔閉鎖機能が改善さ れないものは再手術を考えた方がよい.

3. 構音訓練に重点をおいたとと

てれまでの臨床経験で, 患者たちが受けてき た訓練を聞いてみると，耳の訓練（ear-training）と吹く訓練（blowing exercise）が重視 される割には構音操作のヒント, 誘導などは指 導されずに，ことばを改善するよう求められて きた例が多い。

言語訓練はまず構音訓練に重点をおくべき で, 訓練方法として, 口蓋内圧や経鼻気流々出 をメーターまたはオシログラフでみせるフィー
ドバック (バイオフィードバック)，指や鏡な ごの触覚的, 視覚的援助による口唇音の導入, その他ささやき声の応用, 他の音加の接近 法, 舌位（構音運動時における舌の位置）から

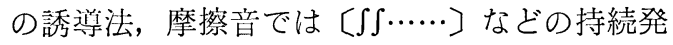
声などを用いる。

当然のととながら構音訓練は単音節, 単語。 文章，会話へと移行すべきであるが，単語へ入 る前に同一単音節や同一行音節（「キカカキ」 など）の連続発音をかなり速く出せるようにす るととが重要だと考えられる.

ただある単音節を「こう言ってでらんなさ い」「いいえ，ちがっています。あう一度言っ てでらんなさい」では駄目で, どうしたら正し い音が出せるようになるか, 各々のケースでヒ ントが与えられるようにしなければならない。 なお，鼻咽腔閉鎖機能不全があっても，鼻を つまんだりして構音異常の改善は可能であり, このような方法で術前より構音訓練をした症例 は，単語レベルまでは正しい構音操作を習得す ることができ，咽頭弁形成術後の訓練期間を短 くし，患者を勇気づけることができた。

4. 会話をよくする工夫

従来, 構音異常は增齢に伴い単語や文章レベ ルで改善できても，それを会話レベルへ移行

(carry over) させるのが困難だと言われてき た.

事実その通りであるが，会話での構音改善の 工夫として, 次のような方法は有効だと考える.

(1)無意味音節の連続発音訓練を重視する. 特 に個々の患者の言いにくい音の組み合わせを見 つけてプログラムを作ることが重要である.

(「カ」について言えば「ナカカラ」の○印の 「カ」が言いにくいなど）.

(2)歌の指導. 各自の訓練する音が多く出てく る. 比較的テンポの速い曲を歌う. 大きな声で 心から楽しく歌った経験のない患者屯かなり多 いので，心理的な解放にもいいし，開鼻声(nasality）を減ずるととあある.

(3)演劇の指導. 一定時間正しく話すようにす 
るだけでなく，他の人格を演じることで心理療 法としても有効である. 患者の興味をひきやす いし，合宿でやれば練習効果が仲間にすぐ認め られるなどの点もよい.

(4)実生活のととばの訓練. 成人の構音異常改 善の困難性を考虑して，日常生活での適応をよ くするため, 改善のできた構音を少しの語数で あできるだけ早く実生活の会話で確実に言える ように訓練した。具体的には単語終了の頃か ら, 日常生活の挨拶, 日常通う駅名, 職場の同 僚の名前, 実務用語, 忘年会用の歌などを訓練 した。

(5)患者の動機づけの配慮. 成人口蓋裂患者の 構音改善が可能だといっても, 子どもと違って 数倍の時間や努力を要することがある. この困 難を乗り越えて，患者を構音改善に立ち向加 すためには，以下のような点に配慮して患者を 動機づけるととが必要である。

ア）患者之担当医師，言語訓練者が深い心の つながり（rapport）を持つ，そのためには患 者の考元や行動, 性格など, いっさいを非難 しないで，ありのままに受容することから始め なければならない。

イ）合宿による集団の力の応用. 仲間意識や 連带感は患者に励みと共に適当な競争心も生 む.

ウ）楽しみながら治す工夫. 合宿に適当なリ クレーションを取り入れて, 集まって来ること そのものに楽しみを与えることもよい. 患者の 好みに応じた詩や落語の暗誦, 歌の訓練など心 理的な生活を豊かにし, 楽しみながら構音を改
善しようと工夫することが大切である.

5. カウンセリング, 集団指導の重視

成人患者の社会不適応，性格の歪みが本人た ちにとっていかに深刻なものであるかは，具体 的に述べた通りである。乙れらに対する理解・ 助言なしに患者の信頼は得られないし，訓練効 果も上がらない。言語障害が性格, 行動の歪み の原因であるにしても, 訓練効果を上げるには, 後者の問題解決にも積極的に努力せねばならな い.

またカウンセリングの中で, 症例(6のように 構音改善が不十分でも, 患者が意識や行動面で 大きく変わり（この場合は話すととへの自信か ら管理職採用試験を受け合格した), 生活が充 実してくれば，患者の自己決定により治すこと にてだわらず，発音の訓練にあまり重きを置か ないように励ますととも大切である.

このように構音改善に打ち込む時期から，治 すととにこだわらない生き方への転換を適時助 言するととあ言語訓練者の重要な役割である.

症例奋は構音が改善し言語訓練をいったん終 了していたが，最近になって「何度お見合いを しても断わられるのではないかという恐怖が先 にたって，つい自分の方から断ってしまう」と いって面接を求めてきた.

今後はこのように構音改善後も患者の心理的 な問題の相談に応じることが多くなるだろう が，問題の性質によっては言語訓練者だけでな く, 精神科医や臨床心理学者など他の分野の尊 門家の援助を仰ぐことが必要かつ適切なととに なると考えられる。

語

(1)口蓋裂言語を有する成人患者に対し言語訓練を行い，かなり満足すべき構音改善成績を得るこ とができた。

(2)言語訓練では構音操作の指導が最む重要と考えられる. 強く吹く訓練は不要で, 煩をふくらま せたり，軽く呼気を吹き出すことから構音操作を教える方がより有効なことが多い.

(3)軽度鼻咽腔閉鎖機能不全があっても，ひどい構音障害を生じることがある，しかし，これは言 語訓練によって改善可能である，ただし，鼻咽腔閉鎖機能不全の判定や言語訓練法を誤ると，構音 の悪習慣をかえって誘発しかねない. 
(4)カウンセリングなどにより，患者の意識や行動を変化させるよう働きかけるととが重要であ る.

(5)構音についての言語訓練は終って屯, 患者は心理的な問題や社会適応について長期にわたって 援助を求めることが多い. 今後はてのためのチーム・アプローチむ重要な問題となる.

(6)言語訓練の場面や方法を訓練室内でのみ行う構音訓練之面接に限っていては好ましい成績はあ げられない. 大学や旅館での学習を重視した症例(1)ように訓練場面も言語訓練担当者の働く場所 も病院の指導室から野外, 合宿などと広く考えるべきである.

註 I）音声言語医学 20 巻 3 号（昭和 54 年 7 月 25 日発 行)

註 2 ）鼻咽腔閉鎖機能限界值は音声と視診および空 気力学的検査の 3 つの判定基準を総合して決定する. 開鼻声は，(1)やや，(2)かなり，(3)非常に，と 3 段階に 分けた場合，(1)以下であり，鼻咽腔抗抵值は $45 \sim 100$ dyne. $\mathrm{sec} / \mathrm{cm}^{5}$ のものをいう.

註 3 ）服部四郎によれば「シ」 $\rightarrow$ 〔ci]，「チ」 $\rightarrow$ 〔 論文では「シ」 $\rightarrow\left[\int \mathrm{i}\right],\left\lceil チ 」 \rightarrow\left[t \int \mathrm{i}\right],\lceil シ 」 \rightarrow\right.$ 〔d3i〕などの簡略表記を用いた。

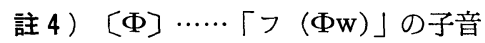

〔u〕 ……音「ウ」

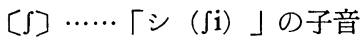

[D] $\cdots$ 「ン」の子音

〔na ……只」の音 (「ガ」の通鼻音)

〔 $\mathrm{k}^{\mathrm{h}}$ ]......音の $\mathrm{k}$ のあとに気息音 $\mathrm{h}$ の音が つづいた音

〔 $\mathrm{t}^{\mathrm{h}}$ 〕...... 音 $\mathrm{t}$ のあとに気息音 $\mathrm{h}$ の音がつ づいた音

[tsa]…「チャ」の音

[tsui $\cdots \cdots \cdot$ …

[६i $\ldots . . . \Gamma$ 「ヒ」の音
文

1) 大橋靖: 口蓋裂治療の予後. 柬界展望, $29: 1493$ 〜 1498, 1967.

2 ) 岡崎恵子, 佐藤美子, 鬼塚卓弥, 赤川徹弥：口蓋 裂言語における口蓋化傾向. 聴覚言語障害 4 ： $8 \sim 15,1975$.

3) Morley, M. E. : Clefs Palate and Speech (7th ed.). E \& S Livingstone Edinburgh and London, 1970.

4 ) 阿部雅子, 福迫陽子, 沢島政行 : 口蓋裂 60 症例の 構音訓練成績. 音声言語医学 18:67〜73, 1977

5 ) 阿部雅子, 沢島政行, 福迫陽子 : 構音障害の I 型 (鼻腔構音) について. 音声言語医学 19:29〜 30, 1978.

6 ）田中幸代 : 口蓋裂の言語治療. $38: 1417 \sim 1425$, 1966.

7 ) Isshiki, N., Honjow, I., and Morimoto, M. :

\section{献}

Indication and the Results of Pharyngeal Flap Operation. Arch. K[in. exp. Ohr.-, Nas. - u. Kehlk. Heilk. $200: 158 \sim 168,1971$.

8 ）相野田紀子, 鈴木重忠: 成人口蓋裂患者の言語治 療経験. 聴覚言語障害 $3: 123 \sim 129,1974$.

9 ）川野通夫, 一色信彦：成人口蓋裂の言語訓練. 音 声言語医学 $20: 255 \sim 261,1979$.

10）本庄殿：口蓋裂音声における鼻咽腔閉鎖度の意 義. 耳鼻臨床 $60 ： 865 \sim 881 ， 1967$.

11）川野通夫, 萩尾藤江 : 唇裂・口蓋裂の相談. 全国 言友会連絡協議会, 1979 .

12）条沢二三子，利重敦子，三日月理子，吉田くすほ み：口蓋裂児理解のための一考察（上）(下). 日 本歯科評論 $445,446: 172 \sim 184,163 \sim 170$, 1979.

13）服部四郎：音声学. 岩波全書, 1951. 